\title{
caso Marpurg-Couperin: apropriação pela via da tradução e consequente autoria
}

\author{
[The Marpurg-Couperin matter: appropriation by means of translation and consequent \\ authorship] \\ http://dx.doi.org/10.11606/1982-8837244366
}

Stéfano Paschoal ${ }^{1}$

\begin{abstract}
This paper intends to discuss the notions of appropriation by means of translation from the analysis of eight excerpts contained in the Preparation to the first part of Die Kunst das Clavier zu spielen by Friedrich Wilhelm Marpurg. The Preparation of this piece of work is composed of 23 paragraphs, eight of which reflect ideas presented in a former production, L'Art de toucher le clavecin (1716), by François Couperin. The reflection of these ideas will be taken into account herein, by means of translation. The translated sections are increased, reduced, or suppressed. Such dynamics are acknowledged by Marpurg in the preface of two issues prior to 1762: the 1750 and 1751 editions. Regarding the discussions on appropriation, we have looked into what possibly would have led Marpurg to refrain from revering Couperin in the prefaces of later editions, which contributed, so that this appropriation - which also occurred, but not only through translation - could be related, in principle, to authorship. In this sense, with the reliance on scientific works on translation and appropriation, the notion of translation, appropriation and authorship have been discussed, and thereby tracing a dialogue with two fields of Translation Studies: comparative analysis and commented translation.
\end{abstract}

Keywords: Marpurg; Couperin; Appropriation, Translation; Authorship.

Resumo: Este trabalho tem como objetivo discutir as noções de apropriação pela via da tradução a partir da análise de oito excertos da Preparação à primeira parte da obra Die Kunst das Clavier zu spielen de Friedrich Wilhelm Marpurg. A Preparação desta obra compõe-se de 23 parágrafos, dos quais oito refletem ideias apresentadas numa obra anterior, a saber, L'Art de toucher le clavecin (1716), de François Couperin. Para este trabalho será considerado o reflexo dessas ideias pela via da tradução. Os trechos traduzidos aparecem ora aumentados, ora reduzidos, ou então são suprimidos. Esta dinâmica de tradução é afirmada por Marpurg no prefácio de duas edições anteriores a 1762: as edições de 1750 e 1751. Investigamos, nas discussões sobre apropriação, o que teria levado Marpurg a abandonar a reverência a Couperin nos prefácios de edições posteriores, o que contribuiu para que essa apropriação - ocorrida também, mas não apenas por meio da tradução - pudesse ser relacionada, a princípio, à autoria. Nesse sentido, apoiados em obras científicas sobre tradução e apropriação, discutimos a noção de tradução, apropriação e autoria, traçando um diálogo com duas áreas dos Estudos da Tradução: análise comparativa e tradução comentada.

Palavras-chave: Marpurg; Couperin; Apropriação, Tradução; Autoria.

\footnotetext{
${ }^{1}$ Universidade Federal de Uberlândia, Instituto de Letras e Linguística, Av. João Naves de Ávila, 2121, Campus Santa Maria, Uberlândia, MG, 38408-100, Brasil. E-mail: stefanotranslatio@gmail.com. ORCID: 0000-0002-7615-7624
}

\section{(c) BY-NC}

Pandaemonium, São Paulo, v. 24, n. 43, mai.-ago. 2021, p. 66-95 
PASCHOAL, S. - O caso Marpurg-Couperin: apropriação pela via da tradução e consequente autoria

\section{Introdução}

Autoria e apropriação - esta última ora como consequência lógica de movimentos tradutórios do passado, ora com viés filosófico na modernidade - têm sido temas recorrentes nos Estudos da Tradução, principalmente por tocarem uma questão polêmica cara à tradução: a fidelidade, que envolve, num certo limite, a literalidade, e cuja problematização, muitas vezes, culmina no insucesso de traçar rigorosamente limites entre original e tradução.

Partindo de um conceito mais amplo de tradução, pretendemos discutir neste artigo os conceitos de apropriação em tradução e apontar como, no caso específico da tradução de trechos da obra L'Art de toucher le clavecin (1716), de François Couperin (1688-1733) e sua alocação na obra Die Kunst das Clavier zu spielen (1750-1762), de Friedrich Wilhelm Marpurg (1718-1795), a autoria ocorre como consequência da apropriação.

No prefácio à primeira edição de sua obra (1750), o autor de Die Kunst das Clavier zu spielen faz menção a François Couperin, mestre francês da música de teclado. Dessa perspectiva, compreendemos que a apropriação de conhecimentos - por meio de um diálogo intertextual profícuo - aproxima-se da tradução na medida em que adapta esses conhecimentos tanto para o público-alvo (jovens aprendizes de instrumentos de teclado) quanto para a cultura de chegada. Além disso, há, de fato, no ato de apropriação marpurguiano, a tradução de oito trechos presentes na introdução da obra francesa, com os quais Marpurg, com base em sua própria experiência como tecladista, lida de modo diverso, ora amplificando-os, ora reduzindo-os e, não raro, suprimindo-os.

As reflexões sobre apropriação e autoria em tradução foram motivadas justamente pela presença desses trechos traduzidos na Preparação (al. Vorbereitung) à primeira parte da obra Die Kunst das Clavier zu spielen (1762), de Friedrich Wilhelm Marpurg (1718-1795), em sua quarta edição, cujos 23 parágrafos da Preparação, em tom propedêutico, contêm traduções da obra L'Art de toucher le clavecin (1716), de François Couperin (1668-1733) em oito de seus trechos.

Essas traduções envolvem questões de apropriação e, consequentemente, autoria, como discutiremos posteriormente. A tradução/apropriação tal qual presenciamos na obra de Marpurg era comum no século XVIII, em que a noção de autoria não tinha muita força, já que os sistemas de direitos autorais não estavam consolidados e, por ser o livro um

Pandaemonium, São Paulo, v. 24, n. 43, mai.-ago. 2021, p. 66-95 
PASCHOAL, S. - O caso Marpurg-Couperin: apropriação pela via da tradução e consequente autoria artigo caro e escasso, eram habituais reimpressões não autorizadas, das quais o autor alemão se queixa no prefácio à sua quarta edição (1762), como será exposto em Die Kunst das Clavier zu spielen: os prefácios.

Em termos metodológicos, este artigo guarda semelhanças com a área de análise de textos paralelos dos Estudos da Tradução (BAKER 1992). Não obstante a semelhança metodológica, os textos paralelos assemelham-se uns aos outros em conteúdo e forma, ainda que não se tratem de traduções.

$\mathrm{O}$ artigo enquadra-se também numa das áreas de pesquisa mais significativas ao longo da história dos Estudos da Tradução: a análise comparativa (HoLMES 2004, WiLliams; CheSTERMAn 2002). Sua ênfase recai sobre a análise textual, envolvendo a comparação de alguns excertos da Preparação de Marpurg com aqueles presentes na obra de Couperin. As análises textuais e comparativas realizadas não têm a pretensão de exaurir todos os possíveis aspectos comparativos de textos (supostamente) "originais" e traduzidos.

Ainda que de forma ilustrativa, este trabalho se envereda, também, por outra área bastante expressiva dos Estudos da Tradução, que é a tradução comentada (SAGER 1997), ao traduzir para o português do Brasil e comentar os excertos de Marpurg em alemão, em referência aos excertos de Couperin, em francês. Esta tarefa de tradução empreendida aqui, seguida da análise de aspectos dos textos em francês e alemão, buscam justificar a hipótese de que textos-fonte e alvo se fundem, formando um continuum. Nas soluções sugeridas em língua portuguesa encontram-se formas de sustentação e descrição da apropriação de Marpurg do texto de Couperin: uma tríade analítica elucidativa, que além de estudar os textos em questão, de caráter histórico e propedêutico, busca, nas vantagens da tradução comentada, compreender os processos de tradução, apropriação e, neste caso, consequente autoria.

Em nossa discussão mostramos que Marpurg, ao longo das edições, deixa de reverenciar Couperin nos prefácios, o que contribui para ilustrar um conceito de apropriação - por intermédio da tradução - que culmina na autoria. Iniciaremos a discussão com um breve histórico sobre Marpurg e sua obra musical.

Pandaemonium, São Paulo, v. 24, n. 43, mai.-ago. 2021, p. 66-95 
PASCHOAL, S. - $\bigcirc$ caso Marpurg-Couperin: apropriação pela via da tradução e consequente autoria

\section{Friedrich Wilhelm Marpurg e sua obra}

Friedrich Wilhelm Marpurg nasceu em 1718 em Wendemark e morreu em 1795 em Berlim. Personalidade atuante no cenário cultural musical berlinense da primeira metade do século XVIII, viajou para a França depois de frequentar a universidade, em 1746, onde conheceu François-Marie Arouet (Voltaire) (1694-1778), e Jean-Baptiste le Rond d'Alembert (1717-1783) e onde buscou assimilar o estilo musical francês, perceptível em algumas de suas composições, dentre as quais se destacam cinco suítes (ao estilo de François Couperin e Jean Philippe-Rameau), sonatas, fugas e caprichos para órgão e cravo.

As obras teóricas de Marpurg são caracterizadas, não raro, pelo tom polêmico constante de sua crítica musical. Dentre elas, podemos mencionar as mais importantes: Der critische Musicus an der Spree (uma coletânea de artigos publicados semanalmente de março de 1749 a fevereiro de 1750); Kritische Briefe über die Tonkunst (1759-1763); Anleitung zum Clavierspielen (1755), publicada também numa tradução francesa do próprio autor sob o título Principes du clavecin (1756); Die Kunst das Clavier zu spielen (1750) e Die Abhandlung von der Fuge (1753). Sua tradução da obra Éléments de musique, de Jean-Philippe Rameau (1683-1764), além de ter contribuído para destacá-lo no meio musical alemão, revela sua proximidade com a música francesa.

Essa proximidade de Marpurg com a música francesa não se dá apenas no âmbito da música teórica. Quando, posteriormente, tratarmos de questões de apropriação, será necessário lembrar que, embora tratemos da apropriação no cerne de uma relação intertextual muito específica, no caso de dois tratados sobre Música, ela ocorre também em outros âmbitos. Como ilustração, apontamos a seguir uma breve citação de Moroney (2003: 122; tradução nossa), em que fica evidente a relação entre o autor alemão e o mestre francês, no âmbito da composição:

Outro tributo desta natureza, não francês, é Les Dryades, de Marpurg, a última peça de seu pouco conhecido primeiro livro de cravo. Não apenas se trata de uma clara referência a Les Sylvains, de Couperin (dríades e silvanos, ambos criaturas mitológicas dos boques e das florestas), mas a obra de Marpurg, como seu modelo, é um rondó duplo em sol 
PASCHOAL, S. - O caso Marpurg-Couperin: apropriação pela via da tradução e consequente autoria

menor que explora o registro grave do cravo. Todo o volume de Marpurg é composto no mais puro estilo francês, o que não surpreende, já que foi publicado apenas em Paris. ${ }^{2}$

A obra de Marpurg possui outra característica marcante: busca extrapolar as fronteiras do público leitor alemão, traduzindo ou concebendo suas obras em francês. É o caso da obra Anleitung zum Clavierspielen (1755), publicada em 1756 sob o título Principes du clavecin (1756). A este respeito, tratando dos Principes du Clavecin, Moroney (2003: 123; tradução nossa) afirma que "Marpurg tentava dar a seu texto uma atmosfera pan-europeia, um dos aspectos mais notáveis de seu livro"3. Não nos parece estranho que Marpurg tenha traduzido sua própria obra para a língua francesa, já que isto ocorrera também com a obra Versuch einer Anweisung die Flöte traversiere zu spielen (1752), de Johann Joachim Quantz (1697-1773), publicada no mesmo ano em francês sob o título Essai d'une méthode pour apprendre à jouer de la flute traversiere, provavelmente uma tradução ou escrita paralela do próprio Quantz, já que não se tem qualquer indicação do tradutor (diferentemente das traduções posteriores para o holandês e para o inglês).

Ao afirmar - a exemplo da obra Principes du clavecin (1756) - que Marpurg buscava dar a seu texto uma atmosfera pan-europeia, Moroney (2003: 124; tradução nossa) expõe uma ressalva: "Entretanto, há também uma tendência nacionalista em Marpurg. O alemão foi a primeira língua em que seu texto foi publicado" ${ }^{4}$. Essa asserção de Moroney levaria a um delongado debate, que não encontra espaço em nossas discussões. Cabe dizer, entretanto, que Marpurg havia traduzido em sua coletânea Der Critische Musicus an der Spree (1750) dois tratados franceses: Essai sur le bon goust em Musique (1732), de Nicolas Ragot de Grandval (1676-1753) e De la Corruption du Goût dans la Musique Françoise (1746), de Louis Bollioud de Mermet (1709-1796). Essas traduções reforçam a afinidade de Marpurg com a cultural musical francesa e o desejo de oferecer a seu público - não necessariamente leitor do francês - os tratados em língua alemã. A discussão sobre a existência de um componente nacionalista nos atos de

\footnotetext{
2 "Another such non-French tribute is Marpurg's Les Dryades, the closing piece of his little-known first harspsichord book. Not only is the same a clear reference to Couperin's Les Sylvains (dryads and sylvans both being mythological creatures of the woods and forests), but Marpurg's work, like its model, is a double rondeau in G minor that exploits the low register of the harpsichord. Marpurg's whole volume is composed in the purest French style, which is not surprising since it was published only in Paris."

3 "Marpurg tried to give his text a pan-European air, one of the more remarkable aspects of the book."

4 "Nevertheless, there is also a nationalistic bias in Marpurg. German was the first language in which his text was published."
}

Pandaemonium, São Paulo, v. 24, n. 43, mai.-ago. 2021, p. 66-95 
PASCHOAL, S. - O caso Marpurg-Couperin: apropriação pela via da tradução e consequente autoria

tradução de Marpurg ou no fato de ele ter escrito uma de suas obras primeiramente em alemão, para depois fazê-lo em francês, ficará reservada para pesquisas futuras.

A primeira metade do século XVIII traduz um momento de grande efervescência cultural na vida musical berlinense. Grandes teóricos da Música - ou tratadistas dedicavam-se à discussão do bom gosto musical, como é o caso de Johann Joachim Quantz (1697-1773) em sua obra Versuch einer Anweisung, die Flöte traversiere zu spielen (1752). O tratamento do gosto (ou bom gosto, ou ainda, formação do gosto) vinha acompanhado de uma série de regras e aconselhamentos de como se devia executar (tocar) música, de forma bastante organizada.

No tratado supramencionado de Quantz, por exemplo, há explicações detalhadas de como se devem executar ornamentos, um Adagio, um Allegro e assim por diante, assim como na obra Der Critische Musicus an der Spree (1750), de Marpurg, há normas de execução, o que aproxima as duas obras, no caso das regras para execução, da quinta parte da Retórica clássica (lat. pronuntiatio ou actio). A formação do gosto musical alemão na primeira metade do século XVIII possui, assim, um componente de normatividade.

No âmbito desta normatividade, de como se deve executar música - algo bastante semelhante à pronuntiatio retórica, que trata de como deve ser proferido determinado discurso - é importante apontar que, nos discursos críticos alemães, dá-se preferência pela música francesa, em detrimento da música italiana.

O tratado Die Kunst das Clavier zu spielen (1750), publicado diversas vezes à mesma época do Versuch über die wahre Art, das Clavier zu spielen (1753/1762) de Carl Ph. E. Bach (1714-1788), não é, dentre os escritos de Marpurg, o de maior profundidade. Por outro lado, não podemos atribuir a ele o rótulo de uma obra menor, pois possui grande importância historiográfica para o ensino de Música (e mais especificamente de instrumentos de teclado), e demonstra, a exemplo deste artigo, formas de apropriação de um conhecimento que se pode dizer compartilhado, como discutiremos posteriormente.

\section{Die Kunst das Clavier zu spielen: as edições}

Ao realizarmos nossas pesquisas acerca da publicação da obra Die Kunst das Clavier zu spielen, de Marpurg, deparamo-nos com diversas edições, todas disponíveis online no sítio da Bayerische Staatsbibliothek (digital). Segundo constatamos, há uma edição em 1750 (Berlim, gedruckt mit Hennigischen Schriften); uma em 1751 (é a primeira Pandaemonium, São Paulo, v. 24, n. 43, mai.-ago. 2021, p. 66-95 
PASCHOAL, S. - O caso Marpurg-Couperin: apropriação pela via da tradução e consequente autoria

publicada por Haude e Spener, que detinham privilégios reais e da Academia de Ciências de Berlim); outra em 1760, denominada terceira edição, revisada e aumentada, também de Haude e Spener; outras duas em 1761, uma publicada em Augsburg (referente à primeira parte da obra, aumentada com algumas observações) e outra, editada por Haude e Spener, referente à segunda parte da obra (a arte do acompanhamento) e, por fim, a quarta edição, revisada e aumentada (Vierte, verbesserte und vermehrte Auflage), publicada por Haude e Spener, em Berlim, em 1762, cujo original se encontra na Niedersächsische Staats- und Universitätsbibliothek Göttingen.

A edição de 1762, com que trabalhamos, contém as duas partes da obra, ou seja, a parte referente a princípios dos instrumentos de teclado (parte 1) e a parte sobre o acompanhamento (parte 2). Esta edição reúne uma cópia reprográfica da quarta edição, revisada e aumentada, de Berlim, 1762, e a cópia reprográfica da edição de Berlim, de 1761 (segunda parte).

Nem todas as edições possuem indicação de número, ou seja, não se informa, na folha do título da obra, se aquela edição é a primeira, a segunda etc. Curiosamente, as indicações ocorrem para a terceira e quarta edições.

A terceira edição, de 1761, não possui prefácio. A quarta edição possui um prefácio em que Marpurg faz menção à terceira edição. Estas são dificuldades comuns ao trabalho com textos de época. Por ora, e para as discussões propostas neste artigo tradução, apropriação e autoria - importa saber: i) que as edições de 1750 e de 1751 possuem um prefácio idêntico, ii) que a terceira edição não possui prefácio e iii) que a quarta edição - de 1762, que reúne as duas partes da obra, e com que trabalhamos - possui dois prefácios.

O prefácio da segunda parte da edição de 1762 mostra-se menos importante para o tratamento de questões atinentes à autoria e apropriação, pois nele - que é o mesmo prefácio da edição da segunda parte isolada, de 1761 - Marpurg informa que a parte sobre acompanhamento foi motivada por diversos pedidos, de vários lugares, para que ele aumentasse a obra com uma segunda parte, não fazendo qualquer menção a ter ou não se apoiado em determinado autor.

Os prefácios da primeira parte das edições de 1750 e 1751 (idênticos) e o da edição de 1762 são cruciais para nossas discussões acerca de apropriação, já que suas diferenças residem, principalmente, na exclusão de informações sobre o fato de Marpurg ter se baseado na obra de François Couperin.

Pandaemonium, São Paulo, v. 24, n. 43, mai.-ago. 2021, p. 66-95 
PASCHOAL, S. - O caso Marpurg-Couperin: apropriação pela via da tradução e consequente autoria

Embora nos concentremos na Preparação à primeira parte da obra de Marpurg, preferimos utilizar uma edição que reunisse as duas partes, por considerarmos assim a obra completa em si. Além disso, outros trabalhos já foram realizados no passado, como a tradução comentada deste tratado, para os quais foram necessárias as duas partes da obra, ou seja, a obra completa, assim concebida em sua quarta edição, de 1762, com a qual estamos mais habituados.

O ponto de partida para nossas discussões sobre apropriação e autoria são as diferenças entre os prefácios das edições de 1750/51 e da edição de 1762. Há outras diferenças entre as edições, como, por exemplo, o número de parágrafos da Preparação: 30 nas edições de 1750/51 e 23 na edição de 1762. Tais diferenças, contudo, não têm impacto sobre a discussão proposta neste artigo, uma vez que os trechos baseados em Couperin contidos nos 23 parágrafos da Preparação mostram-se suficientes para discutirmos aqui o que propomos. As diferenças, principalmente as de conteúdo, entre os parágrafos da Preparação à primeira parte nas edições de 1750/51 e de 1762, ficam reservadas para pesquisas futuras.

Uma vez que trabalharemos apenas com trechos da Preparação à primeira parte, iremos nos restringir a apontar os conteúdos presentes aí. São eles: idade mais adequada para aprender instrumentos de teclado, características do aprendiz, escolha e características do professor, troca de professor e suas consequências, instrumento adequado para o início do aprendizado, afinação do instrumento, posição ao instrumento, advertência a homens que queiram aprender instrumento de teclado, posição das mãos ao instrumento, movimento uniforme das mãos, valor das notas e movimento dos dedos, trinados e mordentes, expressões e gestos no ato da execução musical, estudos na ausência do professor, a importância de decorar pequenos exercícios no início do aprendizado, a necessidade de anotar o dedilhado, leitura de partituras e dedilhado, obediência à gradação de dificuldades por parte do professor, atenção ao andamento, igualdade dos dedos, incluindo-se o polegar e o dedo mínimo, peças musicais (sobre as transcrições), disciplina no desenvolvimento das lições e o aconselhamento a que se dedique a obras de diferentes compositores, uma vez tendo-se obtido certo domínio técnico.

Pandaemonium, São Paulo, v. 24, n. 43, mai.-ago. 2021, p. 66-95 
PASCHOAL, S. - O caso Marpurg-Couperin: apropriação pela via da tradução e consequente autoria

\section{Die Kunst das Clavier zu spielen: os prefácios}

Iremos nos concentrar neste momento nos prefácios das edições de 1751 - deixaremos esta edição definida em detrimento daquela de 1750, por ter sido ela publicada por Haude e Spener, que, além dos privilégios reais e da Academia de Ciências de Berlim, publicaram também a edição de 1762. É necessário considerar que, entre eles, há uma terceira edição (assim denominada) sem prefácio.

Logo no início do prefácio da edição de 1751, Marpurg (1751: 8; tradução nossa), ao se dirigir a seu público, informa: "Talvez o nome Couperin seja conhecido a ti. Tomeio como base. Não te espantes com o fato de que é um francês. [...] Sobre o elogio a Couperin, nada posso te dizer, além de que os músicos da família Bach o consideram digno de aprovação"

Considerando os dizeres de Marpurg - em seu prefácio à edição de 1751 - não nos causa surpresa que alguns trechos de Couperin tenham sido "trasladados" para a obra alemã: a menção a um autor (Couperin) considerado principal para o ensino de instrumentos de teclado no século XVIII e a utilização de sua obra como base é, sobretudo, um gesto de reverência que contribui para a divulgação de determinado conhecimento.

A explicação para os trechos de Couperin aparecerem ora aumentados, ora reduzidos, na obra de Marpurg, encontra-se também no mesmo prefácio, quando o autor informa, logo após o elogio ao mestre francês: "Neste ponto é necessário lembrar que não segui este homem (Couperin) totalmente palavra por palavra. Algumas vezes aparecem minhas próprias ideias e meus próprios exemplos" "(MARPURG 1751: 8; tradução nossa).

Assim, como será mostrado no tópico Couperin em Marpurg: apropriação por tradução, dedicado à análise dos trechos da Preparação, não há coincidência de extensão entre eles, pois, pela natureza da apropriação dos conhecimentos de Couperin, sofreram acréscimos ou foram reduzidos. Importante aqui é observar que se trata de uma apropriação de conhecimentos, na verdade, de um emaranhado de conhecimentos

\footnotetext{
5 „Der Name Couperin ist Dir villeicht bekannt. Diesen habe ich zum Grunde gelegt. Stosse dich nicht daran, daß er ein Franzose ist. [...] Ich kann Dir zum Lobe des Couperin nicht mehr sagen, als daß die gelehrten Bachen ihn ihres Beyfalls würdig schätzen“.

${ }_{6}^{6}$ „Dieses muß hiebey erinnern, daß ich diesem Mann nicht durchgängig von Wort zu Wort gefolget bin. Es sind hin und wieder meine eigene Gedanken und Exempel hinzu gekommen“.

Pandaemonium, São Paulo, v. 24, n. 43, mai.-ago. 2021, p. 66-95
} 
PASCHOAL, S. - O caso Marpurg-Couperin: apropriação pela via da tradução e consequente autoria

técnicos, que, com o passar do tempo, adquirem o status de conhecimento compartilhado ou de autoria diversa (já que a menção ao autor primeiro desaparece dos prefácios).

A edição de 1762 apresenta dois prefácios, um para cada uma das partes (então reunidas numa única edição). Como dissemos anteriormente, as informações do prefácio à segunda parte não são relevantes para nosso trabalho. O prefácio à primeira parte, entretanto, é de suma importância, pois nele é possível perceber, em comparação ao prefácio das edições de 1750/51, que Marpurg deixa de mencionar Couperin: o que motiva nossa discussão.

Com o intuito de demonstrarmos a inexistência de menção a Couperin no prefácio à primeira parte da edição de 1762, bem como a insatisfação de Marpurg com as reproduções não autorizadas de sua obra - de que falamos anteriormente - nós o transcrevemos na íntegra a seguir:

A boa vendagem desta obra, que, não obstante suas numerosas reproduções, não só se esgotou totalmente por três vezes em doze anos, mas também foi reproduzida - ainda que sem permissão e de forma muito deficiente - numa certa cidade do Reich, mostra que sua existência não viria a passar desapercebida do público. Sou tão pouco insensível a esta receptividade, que esforcei-me de todas as formas para tornar o trabalho ainda mais digno para os meus nesta terceira edição regular, que é a única que reconheço, por meio de vários acréscimos e modificações. Uma vez que esta obra, como se pode perceber, é dedicada aos iniciantes do teclado, pode-se então, uma vez dominados os princípios básicos deste instrumento, adotar minha obra Anleitung zum Clavierspielen, maior, publicada por essa mesma editora e em consonância com a mais bela prática dos dias atuais. Desejo a todos os amantes da Arte sorte em seus esforços e recomendo os meus (esforços) à contínua aceitação benevolente do público (MARPURG 1762: 3; tradução nossa) ${ }^{7}$.

Conforme observarmos, não há, de fato, menção ao mestre francês no prefácio da edição de 1762, não obstante a presença de oito trechos retirados e devidamente modificados na Preparação à primeira parte (da obra alemã). Várias hipóteses nos remetem à supressão do nome de Couperin do prefácio da edição de 1762, dentre elas: i) a consideração de que todos tinham acesso àquele conhecimento como oriundo do mestre

\footnotetext{
7 „Der gute Abgang dieses Werkchens, welches seiner zahlreichen Abdrücke ungeachtet, innerhalb zwölf Jahren nicht allein dreymal gänzlich vergriffen, sondern annoch wiewohl auf eine unerlaubte Art, und sehr fehlerhaft in einer gewissen Reichstadt nachgedruckt worden, zeiget, daß die Existenz desselben dem Publico nicht gleichgültig seyn müsse. Ich bin bei dieser Gütigkeit so wenig unempfindlich, daß ich vielmehr auf alle Weise bemühet habe, mich derselben bey dieser dritten rechtmäßigen Ausgabe, die ich nur für die meinige erkennen werde, durch allerhand Zusätze und Veränderungen, annoch würdiger zu machen. Da dieses Werkchen, wie es der Augenschein giebt, nur bloß den Anfängern des Claviers gewidmet ist: so kann man, wenn man die darinnen abgehandelten Grundsätze dieses Instruments in seiner Gewalt hat, alsdenn meine grössere Anleitung zum Clavierspielen nach der schönen Ausübung der heutigen Zeit, die in eben diesem Verlage herausgekommen ist, zur Hand nehmen. Ich wünsche allen Liebhabern der Kunst Glück zu ihren Bemühungen, und empfehle die meinigen dem fernern geneigten Wohlwollen des Publici“.
}

Pandaemonium, São Paulo, v. 24, n. 43, mai.-ago. 2021, p. 66-95 
PASCHOAL, S. - O caso Marpurg-Couperin: apropriação pela via da tradução e consequente autoria

francês; ii) a consideração de que tenha havido uma intervenção arbitrária do editor, para retirar qualquer rastro de que se tratava de uma apropriação ou edição de divulgação, para, assim, adquirir certo status ou respeito frente aos acadêmicos alemães; iii) a ponderação de Marpurg de que o material de Couperin que lhe servira de base, por meio de modificações, ora aumentos, ora reduções, tenha se tornado um material muito diverso do primeiro e, por isso, de sua autoria apenas; iv) a consideração de que se tratava de um conhecimento compartilhado, pois os tópicos baseados em Couperin haviam se tornado uma tendência no ensino e aprendizagem de instrumentos de teclado.

Em seguida, antes das discussões sobre tradução, apropriação e autoria, apresentaremos os trechos de Couperin traduzidos na obra Die Kunst das Clavier zu spielen (1762).

\section{Couperin em Marpurg: apropriação por tradução}

Nesta seção apresentaremos o confronto entre os trechos presentes na obra Die Kunst das Clavier zu spielen (1762) e trechos da obra L'Art de toucher le clavecin (1716). Este confronto servirá como ilustração para comprovar a apropriação dos trechos selecionados por meio da tradução.

Indicaremos os trechos em pequenas tabelas, lado a lado (do lado esquerdo, o texto de Marpurg e, do lado direito, o texto francês, de Couperin). Apresentaremos ainda na terceira coluna (à direita) uma sugestão nossa de tradução realizada a partir do texto alemão. Abaixo da tabela, comentaremos o trecho de Marpurg em relação ao texto de Couperin, quando julgarmos necessário. Traduções do francês para o português também são nossas.

Os comentários são breves e apontam apenas as decisões mais simplesmente perceptíveis em relação ao texto de Couperin. Não se pretende, com eles, esboçar hipóteses sobre método de tradução ou ainda o perfil de Marpurg como tradutor. O objetivo aqui é exclusivamente demonstrar que os trechos a seguir, em alemão, são apropriações dos trechos em francês pela via da tradução.

Pandaemonium, São Paulo, v. 24, n. 43, mai.-ago. 2021, p. 66-95 
PASCHOAL, S. - O caso Marpurg-Couperin: apropriação pela via da tradução e consequente autoria

\section{Trecho 1}

O primeiro trecho apresentado diz respeito ao primeiro parágrafo da Preparação da obra de Marpurg.

\begin{tabular}{|c|c|c|}
\hline Marpurg & Couperin & Tradução \\
\hline $\begin{array}{l}\text { Das bequemste Alter zum } \\
\text { Anfange des Clavierspielens ist } \\
\text { das sechste bis siebente Jahr, } \\
\text { nicht, daß dieses ältere } \\
\text { Personen ausschliessen solle, } \\
\text { sondern weil man alsdenn } \\
\text { natürlicher Weise die Hände zur } \\
\text { mechanischen Ausübung des } \\
\text { Flügels am leichtesten } \\
\text { gewöhnen kann. }\end{array}$ & $\begin{array}{l}\text { L'âge propre à commencer les } \\
\text { enfants, est de six à sept ans, } \\
\text { non pas que cela doive exclure } \\
\text { les personnes plus avancées, } \\
\text { mais naturellement, pour } \\
\text { mouler et former des mains à } \\
\text { l'exercice de clavecin, le plutôt } \\
\text { est le mieux; et comme la bonne } \\
\text { grâce y est nécessaire il faut } \\
\text { commencer par la position du } \\
\text { corps. }\end{array}$ & $\begin{array}{l}\text { A idade mais adequada para se } \\
\text { começar a tocar instrumentos de } \\
\text { teclado é de seis a sete anos. } \\
\text { Não que isto deva excluir } \\
\text { pessoas mais velhas, mas as } \\
\text { pessoas daquela faixa etária têm } \\
\text { uma facilidade natural para } \\
\text { adaptar com maior facilidade as } \\
\text { mãos aos exercícios mecânicos } \\
\text { do teclado. }\end{array}$ \\
\hline
\end{tabular}

Os trechos de Marpurg e de Couperin, no tocante à forma e ao conteúdo, são praticamente idênticos. São perceptíveis três modificações mínimas, que não interferem no conteúdo: a primeira delas diz respeito ao predicativo de idade (Alter, âge). A idade apropriada, para Couperin, passa à idade mais confortável para Marpurg, compreendida na tradução proposta como adequada. No texto em alemão há o verbo gewöhnen (acostumar), enquanto em francês temos mouler et former (moldar e formar, ajustar e formar), referente à forma da mão para o exercício no instrumento de teclado. Por fim, o último trecho da observação em francês, et comme la bonne grâce y est nécessaire, il faut commencer par la position (e como a elegância é necessária, é necessário começar pela posição) foi suprimida.

\section{Trecho 2}

O segundo trecho apresentado diz respeito ao sétimo parágrafo da Preparação da obra de Marpurg.

\begin{tabular}{|l|l|l|}
\hline Marpurg & Couperin & Tradução \\
\hline Damit die Füsse junger & On doit mettre quelque chose de & Para que os pés das crianças não \\
Personen nicht in der Luft & plus, ou de moins haut sous les & fiquem balançando no ar e para \\
schweben, und der Körper nicht & pieds des jeunes personnes, à & que o corpo não perca o seu \\
aus seinem Gleichgewichte & mesure qu'elles croissent, afin & equilíbrio, deve-se atentar para \\
gebracht werde: so sorge man & que leurs pieds n'étant point en & que, de acordo com sua estatura, \\
dafür, daß sie, nach & l'air, puissent soutenir le corps & seja-lhe providenciado um apoio \\
Beschaffenheit ihrer Grösse, ein & dans un juste équilibre. & confortável para os pés. \\
dazu bequemes Fußgestell & & \\
erhalten. & & \\
\hline
\end{tabular}


PASCHOAL, S. - O caso Marpurg-Couperin: apropriação pela via da tradução e consequente autoria

No trecho 2 houve uma reorganização de períodos, ou seja, Marpurg escolheu uma ordem diferente daquela constante do texto de Couperin. Veja-se:

\begin{tabular}{|l|l|}
\hline $\begin{array}{l}\text { Damit die Füsse jüngerer Personen nicht in der } \\
\text { Luft schweben }\end{array}$ & [...] afin que leurs pieds n 'étant point en l'air \\
\hline $\begin{array}{l}\text { Und der Körper nicht aus seinem Gleichgewichte } \\
\text { gebracht werde: }\end{array}$ & $\begin{array}{l}\text { [a fin qu'elles] puissent soutenir le corps dans un } \\
\text { juste équilibre }\end{array}$ \\
\hline $\begin{array}{l}\text { So sorge man dafür, daß sie, nach Beschaffenheit } \\
\text { ihrer Grösse, ein dazu bequemes Fußgestell } \\
\text { erhalten. }\end{array}$ & $\begin{array}{l}\text { On doit mettre quelque chose de plus, ou de } \\
\text { moins haut sous les pieds de jeunes personnes, à } \\
\text { mesure qu'elles croissent. }\end{array}$ \\
\hline
\end{tabular}

As duas diferenças mínimas entre o texto de Marpurg e o de Couperin, além da reorganização no texto alemão, dizem respeito à conjunção proporcional à mesure, em à mesure qu'il croissent (à medida que forem crescendo), que não aparece na tradução, e a opção por bequemes (confortável), que recupera a ideia de de plus ou de moins haut (de maior ou menor altura).

\section{Trecho 3}

O terceiro trecho apresentado diz respeito ao décimo-terceiro parágrafo da Preparação da obra de Marpurg.

\begin{tabular}{|c|c|c|}
\hline Marpurg & Couperin & Tradução \\
\hline $\begin{array}{l}\text { In Ansehung der Minen und } \\
\text { Gebärden ist kein besser Mittel, } \\
\text { die unanständigen zu } \\
\text { verbessern, als daß man einen } \\
\text { Spiegel vor sich auf den } \\
\text { Clavierpult setzet, und sich } \\
\text { danach beurtheilet. Zu den } \\
\text { Spielgrimassen gehöret noch die } \\
\text { Gewohnheit einiger Personen, } \\
\text { den Tact mit dem Kopfe, mit } \\
\text { starken Fußschlägen, oder gar } \\
\text { mit dem ganzen Leibe zu } \\
\text { bemerken. Kann sich jemand } \\
\text { ohne die Bewegung seiner } \\
\text { Füsse nicht im Tact erhalten: } \text { so } \\
\text { muß man sie zum wenigsten den } \\
\text { Ohren andrer unempfindbar } \\
\text { machen. (grifo nosso) }\end{array}$ & $\begin{array}{l}\text { A l'égard des grimaces du } \\
\text { visage on peut s'en corriger soi- } \\
\text { même en mettant un miroir sur } \\
\text { le pupitre de l'épinette, ou du } \\
\text { clavecin. }\end{array}$ & $\begin{array}{l}\text { Com relação a expressões e } \\
\text { gestos, não há nenhum artifício } \\
\text { melhor para se corrigir aqueles } \\
\text { inadequados do que colocar um } \\
\text { espelho a sua frente, na estante } \\
\text { do teclado, avaliando-se. Entre } \\
\text { as manias, há a de marcar o } \\
\text { compasso com a cabeça, ou com } \\
\text { uma forte batida dos pés ou até } \\
\text { mesmo com o corpo todo. Se } \\
\text { alguém não consegue se manter } \\
\text { no compasso sem fazer } \\
\text { movimento com os pés, o } \\
\text { mínimo que se pode fazer é } \\
\text { cuidar para que isto não seja } \\
\text { perceptível aos ouvintes. }\end{array}$ \\
\hline
\end{tabular}

A respeito deste trecho, à primeira vista percebemos que a parte sublinhada em alemão não consta do original francês, tendo sido um acréscimo de Marpurg. A parte anterior a esta é uma tradução, com diferenças mínimas. Em grimaces du visage, o termo grimace foi aumentado para Minen und Gebärden. Houve uma expansão por meio da 
PASCHOAL, S. - $\bigcirc$ caso Marpurg-Couperin: apropriação pela via da tradução e consequente autoria inclusão de ist kein besser Mittel, die unanständigen zu verbessern (não há nenhum artifício melhor para se corrigir os inadequados [gestos]).

\section{Trecho 4}

O quarto trecho apresentado diz respeito ao nono parágrafo da Preparação da obra de Marpurg.

\begin{tabular}{|c|c|c|}
\hline Marpurg & Couperin & Tradução \\
\hline 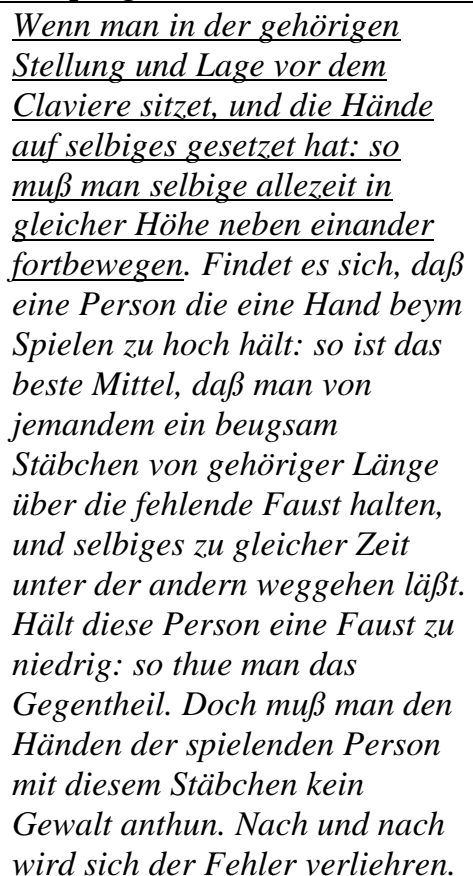 & $\begin{array}{l}\text { Si une personne a un poignet } \\
\text { trop haut en jouant, le seul } \\
\text { remède que j'aie trouvé, est de } \\
\text { faire tenir une petite baguette } \\
\text { pliante par quelqu'un, laquelle } \\
\text { sera placée par dessus le } \\
\text { poignet défectueux, et en même } \\
\text { temps pardessous l'autre } \\
\text { poignet. Si le défaut est opposé, } \\
\text { on fera le contraire. Il ne faut } \\
\text { pas, avec cette baguette, } \\
\text { contraindre absolument celui, } \\
\text { ou celle qui joue. Petit à petit ce } \\
\text { défaut se corrige; et cette } \\
\text { invention m'a servie très } \\
\text { utilement. }\end{array}$ & $\begin{array}{l}\text { Quando se está sentado diante } \\
\text { do teclado na posição e lugar } \\
\text { adequados e se colocam as } \\
\text { mãos sobre ele, deve-se } \\
\text { movimentá-las sempre na } \\
\text { mesma altura. Se uma pessoa } \\
\text { está com a mão muito levantada } \\
\text { ao tocar, então a melhor } \\
\text { maneira de se corrigir é que se } \\
\text { segure um bastão flexível sobre } \\
\text { o punho em questão, deixando } \\
\text { que ele alcance o outro punho } \\
\text { por baixo. Se a pessoa estiver } \\
\text { com o punho muito baixo, então } \\
\text { faz-se o contrário. Deve-se } \\
\text { prestar atenção para que com } \\
\text { este bastão não se cometa } \\
\text { violência alguma às mãos da } \\
\text { pessoa que está tocando. Aos } \\
\text { poucos, por meio disso, este } \\
\text { erro deixa de existir. }\end{array}$ \\
\hline
\end{tabular}

A primeira parte deste trecho, grifada em alemão, não consta do texto francês. A segunda parte do trecho é uma tradução, com as seguintes diferenças (também mínimas): die Hand, na primeira parte da tradução alemã, corresponde ao punho, em francês, poignet, embora nas ocorrências posteriores corresponderá a poignet no texto alemão o termo Faust (punho). No texto francês, seul remède (único remédio) aparece com o melhor meio (das beste Mittel) no texto alemão. Couperin aconselha que não se deve praticar qualquer violência, com o bastão, contra aquele ou aquela que toca (que executa a peça musical). Marpurg detalha: não se deve cometer qualquer violência às mãos da pessoa que está tocando. Há no final do texto francês a informação de que este método de correção foi bastante útil ao professor (Couperin). Esta avaliação do método inexiste no texto alemão. 
PASCHOAL, S. - O caso Marpurg-Couperin: apropriação pela via da tradução e consequente autoria

\section{Trecho 5}

O quinto trecho apresentado diz respeito ao quinto parágrafo da Preparação da obra de Marpurg.

\begin{tabular}{|c|c|c|}
\hline Marpurg & Couperin & Tradução \\
\hline $\begin{array}{l}\text { Zum Instrumente bediene man } \\
\text { sich im Anfange für sehr junge } \\
\text { Personen eines blossen } \\
\text { Clavichords, eines Spinettes } \\
\text { oder eines einzigen Registers } \\
\text { auf einem Flügel, und sehe } \\
\text { darauf, daß auf letztern } \\
\text { Instrumenten die Docken sehr } \\
\text { schwach befiedert seyn. An } \\
\text { diesem Punct ist sehr viel } \\
\text { gelegen, indem die schöne } \\
\text { Ausführung oder Execution } \\
\text { mehr von der Biegsamkeit } \\
\text { geschmeidiger und freyer } \\
\text { Finger, als von der Stärke } \\
\text { abhänget; und, wenn man ein } \\
\text { Kind auf einem stark bekielten } \\
\text { Flügel spielen läßt, so muß es } \\
\text { nothwendig seine zarten Hände } \\
\text { mit aller Macht anstrengen, die } \\
\text { Tasten anzugeben. Hievon aber } \\
\text { entstehet das rauhe und harte } \\
\text { Spielen, und die so unförmliche } \\
\text { Lage der Hände. Der Flügel ist } \\
\text { deswegen besser als ein } \\
\text { Clavichord, weil der Ton sich } \\
\text { nicht so bald darauf verliert, } \\
\text { und man folglich eher hört, ob } \\
\text { der Scholar, nach erloschenem } \\
\text { Werthe der Note, die Finger } \\
\text { hurtig von den Tasten abhebet, } \\
\text { oder nicht, und man ihn } \\
\text { dadurch vor der kleberichten } \\
\text { Spielart bewahren kann. Doch } \\
\text { muß der Flügel, wie gesagt, } \\
\text { sehr schwach bekielt seyn, und } \\
\text { noch ist es gut, nur ein einziges } \\
\text { Register zu nehmen. }\end{array}$ & $\begin{array}{l}\text { On ne doit se servir d'abord que } \\
\text { d'une épinette, ou d'un seul } \\
\text { clavier de clavecin pour la } \\
\text { première jeunesse; et que l'une, } \\
\text { ou l'autre soient emplumés très } \\
\text { faiblement; cet article étant } \\
\text { d'une conséquence infinie, la } \\
\text { belle exécution dépendant } \\
\text { beaucoup plus de la souplesse, } \\
\text { et de la grande liberté des } \\
\text { doigts, que de la force; en sorte } \\
\text { que dès les commencements si } \\
\text { on laisse jouer un enfant sur } \\
\text { deux claviers, il faut de toute } \\
\text { nécessité qu'il ouvre ses petites } \\
\text { mains pour faire parler les } \\
\text { touches et de là viennent les } \\
\text { mains mal placées, et la dureté } \\
\text { du jeu. }\end{array}$ & $\begin{array}{l}\text { Como instrumento, para pessoas } \\
\text { mais jovens, no início, faz-se } \\
\text { uso apenas de um clavicórdio, } \\
\text { de uma espineta ou de um único } \\
\text { teclado de um cravo e, neste } \\
\text { último instrumento, atente-se } \\
\text { para que os saltarelos estejam } \\
\text { suavemente emplumados. Muita } \\
\text { coisa depende disto, pois a bela } \\
\text { execução relaciona-se mais à } \\
\text { elasticidade de dedos livres do } \\
\text { que à força e, se uma criança } \\
\text { tocar em um teclado com } \\
\text { plectros duros, precisará } \\
\text { empregar toda a força de sua } \\
\text { mão delicada. Daí surgem o } \\
\text { toque áspero e duro e a posição } \\
\text { tão disforme das mãos. O cravo } \\
\text { é, por isso, melhor do que um } \\
\text { clavicórdio, pois o som não se } \\
\text { perde tão depressa e, } \\
\text { consequentemente, pode-se } \\
\text { ouvir se o discípulo levanta ou } \\
\text { não os dedos rapidamente } \\
\text { depois de decorrido o valor das } \\
\text { notas, evitando, assim, que ele } \\
\text { toque de maneira inadequada. O } \\
\text { cravo, como foi dito, deve estar } \\
\text { emplumado de maneira muito } \\
\text { suave e é aconselhável que se } \\
\text { utilize um único registro. }\end{array}$ \\
\hline
\end{tabular}

Neste trecho percebemos, novamente, que o texto de Marpurg foi expandido. A última parte, grifada em alemão, não se encontra no texto francês. Não se percebem aí diferenças na ordem das informações, mas ocorre algo bastante interessante: embora seja perceptível tratar-se de uma tradução, os instrumentos aconselhados para o início do aprendizado variam um pouco. Enquanto Couperin aconselha uma espineta ou um único registro de um cravo, Marpurg, além desses dois instrumentos, aconselha também o clavicórdio (partes destacadas nos textos alemão e francês). $\mathrm{O}$ teclado com plectros duros 
PASCHOAL, S. - O caso Marpurg-Couperin: apropriação pela via da tradução e consequente autoria do texto alemão (auf einem stark bekielten Flügel) ${ }^{8}$ corresponde ao sur deux claviers (em dois teclados, de um cravo, certamente) do francês, ou seja, quando se ajusta o registro do cravo para que, tocando-se num dos teclados, sejam acionadas as teclas também do outro, o que confere às teclas mais peso, exigindo mais força do executante. A força é justamente a razão pela qual isto deve ser evitado, pois contribui para mãos disformes e toque duro, áspero. Marpurg concentra-se na força das mãos (anstrengen), enquanto Couperin relaciona a ideia de força dos dedos à abertura da mão (qu’il ouvre...).

\section{Trecho 6}

O sexto trecho apresentado diz respeito ao décimo-quarto parágrafo da Preparação da obra de Marpurg.

\begin{tabular}{|c|c|c|}
\hline Marpurg & Couperin & Tradução \\
\hline $\begin{array}{l}\text { In den erstern Stunden der } \\
\text { Unterweisung ist es gar nicht } \\
\text { rathsam, junge Personen in } \\
\text { Abwesenheit des Meisters zur } \\
\text { Ueberstudirung ihrer Lection } \\
\text { anzuhalten. Sie sind zu flüchtig, } \\
\text { als daß ihre Hände in der ihnen } \\
\text { vorgeschlagenen Lage zu } \\
\text { erhalten, sich die Mühe geben } \\
\text { sollten. Sie können durch eine } \\
\text { üble Wiederholung in einem } \\
\text { Augenblick niederreissen, was } \\
\text { ein geschickter Meister in einer } \\
\text { Zeit von drey Viertheilstunden } \\
\text { mit Sorgfalt gebauet hat. }\end{array}$ & $\begin{array}{l}\text { Il est mieux, pendant les } \\
\text { premières leçons qu'on donne } \\
\text { aux enfants de ne leur point } \\
\text { recommander d'étudier en } \\
\text { l'absence de la personne qui } \\
\text { leur enseigne. Les petites } \\
\text { personnes sont trop dissipées } \\
\text { pour s'assujettir à tenir leurs } \\
\text { mains dans la situation qu'on } \\
\text { leur a prescrite. Pour moi, dans } \\
\text { les commencements des enfans } \\
\text { j'emporte par précaution la clef } \\
\text { de l'instrument sur lequel je } \\
\text { leur montre afin qu'en mon } \\
\text { absence ils ne puissent pas } \\
\text { déranger en un instant ce que } \\
\text { j'ai bien soigneusement posé en } \\
\text { trois quarts d heures. }\end{array}$ & $\begin{array}{l}\text { No início da aprendizagem, não } \\
\text { é recomendável que o aluno } \\
\text { estude na ausência do professor. } \\
\text { Eles são tão descuidados, que } \\
\text { não se dão ao trabalho de } \\
\text { posicionar suas mãos de forma } \\
\text { adequada. Podem, através de } \\
\text { uma repetição inadequada, } \\
\text { destruir em um instante o que } \\
\text { um professor cuidadoso } \\
\text { construiu com dedicação em } \\
\text { quarenta e cinco. }\end{array}$ \\
\hline
\end{tabular}

Neste trecho há apenas a supressão da parte grifada em francês: "Pour moi, dans les commencements des enfants j'emporte par précaution la clef de l'instrument sur lequel je leur montre [...]" (De minha parte, ao iniciar as crianças ao teclado, levo comigo por precaução a chave do instrumento em que as ensino).

\footnotetext{
${ }^{8}$ Bekielen e befiedern são sinônimos. Segundo o Deutsches Wörterbuch der Gebrüder Grimm, bekielen: pennis instruere, befiedern. 
PASCHOAL, S. - O caso Marpurg-Couperin: apropriação pela via da tradução e consequente autoria

\section{Trecho 7}

O sétimo trecho apresentado diz respeito ao décimo-quinto parágrafo da Preparação da obra de Marpurg.

\begin{tabular}{|c|c|c|}
\hline Marpurg & Couperin & Tradução \\
\hline $\begin{array}{l}\text { Man gewöhne sich die Tasten } \\
\text { geschwinde zu finden, damit } \\
\text { man, wenn man nach Noten } \\
\text { spielet, nicht verbunden sey, } \\
\text { alle Augenblick mit den Augen } \\
\text { aufs Clavier, und wieder auf das } \\
\text { Buch zurück zu springen. Man } \\
\text { muß aber nicht eher anfangen, } \\
\text { junge Personen aufs Blatt sehen } \\
\text { zu lassen, als bis sie allerhand } \\
\text { kleine Vorübungsstücke in den } \\
\text { Händen haben. Es ist oft fast } \\
\text { unmöglich, daß, wenn sie die } \\
\text { Augen auf die Noten richten } \\
\text { müssen, ihre Finger nicht in } \\
\text { Unordnung gerathen, sich } \\
\text { verdrehen, und daß besonders } \\
\text { die Manieren nicht darunter } \\
\text { leiden sollten. Man lasse sie im } \\
\text { Anfange alles auswendig } \\
\text { lernen. An der Anständigkeit } \\
\text { und Zierlichkeit im Spielen ist } \\
\text { eben so viel, ja fast noch mehr } \\
\text { als an der Kunst nach Noten zu } \\
\text { spielen, gelegen; und hernach } \\
\text { machen es zween oder drey } \\
\text { Monate mehr oder weniger } \\
\text { nicht aus. }\end{array}$ & $\begin{array}{l}\text { On devrait ne commencer à } \\
\text { montrer la tablature aux enfants } \\
\text { qu après qu'ils ont une certaine } \\
\text { quantité de pièces dans les } \\
\text { mains. Il est presque impossible, } \\
\text { qu'en regardant leur livre, les } \\
\text { doigts ne se dérangent, et ne se } \\
\text { contorsionnent, que les } \\
\text { agréments même n'en soient } \\
\text { altérés. D'ailleurs, la mémoire } \\
\text { se forme beaucoup mieux en } \\
\text { apprenant par coeur. }\end{array}$ & $\begin{array}{l}\text { Deve-se acostumar o aluno a } \\
\text { encontrar as teclas com presteza } \\
\text { para que, quando tocar com } \\
\text { partitura, não fique olhando ora } \\
\text { para o teclado e ora para o livro. } \\
\text { Não se deve deixar o aluno } \\
\text { tocar com partitura antes que } \\
\text { domine pequenos exercícios. É } \\
\text { praticamente impossível que, } \\
\text { quando estes tenham que dirigir } \\
\text { os olhos à partitura, seus dedos } \\
\text { não se enrosquem e que } \\
\text { principalmente os ornamentos } \\
\text { não sejam prejudicados com } \\
\text { isso. Faz-se com que aprendam } \\
\text { tudo de cor no início. Dá-se } \\
\text { muita importância à elegância } \\
\text { na maneira de tocar. Aliás, } \\
\text { muito mais importância do que } \\
\text { na habilidade de ler partituras; } \\
\text { e, por isso, não importa que } \\
\text { sejam dois meses a mais ou a } \\
\text { menos de estudo. }\end{array}$ \\
\hline
\end{tabular}

À primeira vista, percebemos que as partes grifadas no texto alemão - o início e o fim - constituem acréscimos de Marpurg à matéria. Há apenas uma pequena diferença a respeito da memória: embora seja um aconselhamento válido em ambos os textos que o aluno, no início, decore pequenos exercícios, apenas o texto francês aponta que isto contribui para a formação da memória ("D’ailleurs, la mémoire se forme beaucoup mieux en apprenant par coeur").

\section{Trecho 8}

O oitavo trecho apresentado diz respeito ao oitavo parágrafo da Preparação da obra de Marpurg. 
PASCHOAL, S. - O caso Marpurg-Couperin: apropriação pela via da tradução e consequente autoria

\begin{tabular}{|c|c|c|}
\hline Marpurg & Couperin & Tradução \\
\hline $\begin{array}{l}\text { Personen männlichen } \\
\text { Geschlechts, die einen gewissen } \\
\text { Grad der Fertigkeit auf dem } \\
\text { Clavier erhalten wollen, müssen } \\
\text { sich vor aller schweren } \\
\text { Handarbeit in Acht nehmen. Die } \\
\text { Hände des Frauenzimmers sind } \\
\text { aus dieser Ursache insgemein } \\
\text { besser. }\end{array}$ & $\begin{array}{l}\text { Les hommes qui veulent arriver } \\
\text { à un certain degré de perfection } \\
\text { ne devraient jamais faire aucun } \\
\text { exercice pénible de leurs mains. } \\
\text { Celles des femmes, par la raison } \\
\text { contraire, sont généralement } \\
\text { meilleures. J'ai déja dit, que la } \\
\text { souplesse des nerfs contribue } \\
\text { beaucoup plus, au bien-jouer, } \\
\text { que la force. Ma preuve est } \\
\text { sensible dans la différence des } \\
\text { mains des femmes, à celles des } \\
\text { hommes; et de plus, la main } \\
\text { gauche des hommes, dont ils se } \\
\text { servent moins dans les } \\
\text { exercices, est communément la } \\
\text { plus souple au clavecin. }\end{array}$ & $\begin{array}{l}\text { Homens que queiram alcançar } \\
\text { um certo grau de habilidade no } \\
\text { teclado devem evitar qualquer } \\
\text { trabalho manual pesado. Por } \\
\text { isso, geralmente, as mãos das } \\
\text { mulheres são melhores. }\end{array}$ \\
\hline
\end{tabular}

Neste trecho, percebemos que a última parte do texto francês não foi traduzida. De resto, à exceção de uma forma de dizer diversa de les hommes (os homens) por Personen männlichen Geschlechts (pessoas de sexo masculino), o texto é coincidente.

Oferecemos aqui a tradução para a parte do texto de Couperin que não consta do texto de Marpurg:

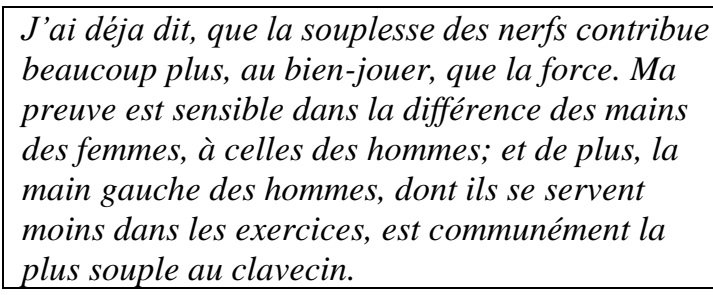
beaucoup plus, au bien-jouer, que la force. Ma preuve est sensible dans la différence des mains des femmes, à celles des hommes; et de plus, la main gauche des hommes, dont ils se servent moins dans les exercices, est communément la plus souple au clavecin.

Eu já disse que a suavidade dos nervos contribui muito mais que a força para que se toque bem. Minha demonstração é perceptível na diferença das mãos das mulheres, em relação às mãos dos homens; e, além disso, a mão esquerda dos homens, da qual eles se servem menos no trabalho, é geralmente a mais suave ao cravo.

Os oito trechos que mostramos anteriormente são as traduções contidas entre os 23 parágrafos da Preparação à primeira parte da obra Die Kunst das Clavier zu spielen, de F.W.Marpurg.

Como foi possível perceber a partir da apresentação dos trechos em alemão cotejados com os trechos em francês, Marpurg traduziu parte deles e, conforme acreditou ser necessário, adaptou, de certo modo, as informações, ora as estendendo, ora reduzindo, ora suprimindo: um expediente em consonância com o que afirmara no prefácio de sua obra publicada em 1751. Ainda que se trate de uma recolocação dos trechos e que, para tal, tenha havido adaptação (no sentido de aumento, diminuição ou supressão de trechos da obra original em francês), a reapresentação das ideias do mestre francês numa obra alemã, dedicada a outro público-alvo, e numa outra língua, permite afirmar a apropriação (não no sentido negativo, mas no sentido de compartilhar determinado conhecimento) por 
PASCHOAL, S. - O caso Marpurg-Couperin: apropriação pela via da tradução e consequente autoria meio da tradução. Lembremo-nos ainda de que no prefácio da edição de 1762 diferentemente daqueles constantes das edições de 1750 e de 1751 - não há qualquer menção à obra de Couperin ou a seu nome.

Assim, a apropriação de que falamos aqui ocorre por meio não apenas, mas também, da tradução: entretanto, não daquela em que um tradutor recorre a expedientes de adaptação devidos à necessidade de uma acomodação morfossintática das ideias do original, mas daquela em que, advertidamente, o tradutor recorre a esses expedientes por considerar a obra primeira a base em que espelhará uma segunda obra. A ausência da menção no prefácio - para o que levantamos algumas hipóteses na Introdução - não aponta para uma apropriação pacífica ou ingênua com o intuito de divulgar o conhecimento de outrem. Antes, realiza-se com o intuito de apresentar um conhecimento que, a partir de certa modelagem, considera seu.

Apesar de serem mínimas as modificações nos trechos cotejados, apontando para uma tradução praticamente literal, não se pode dizer que a obra de Marpurg é uma tradução da obra de Couperin, pois consideramos, aqui, oito trechos, espalhados em 23 parágrafos, apenas na Preparação à primeira parte da obra. Ou seja, o conhecimento apropriado aqui perfaria uma porcentagem baixa, em comparação com todo o restante da obra Die Kunst das Clavier zu spielen.

\section{Tradução, apropriação e autoria}

O título desta seção contém dois conceitos complexos e passíveis, tanto quanto o conceito de tradução, de uma interpretação lato sensu. Perquiridos à luz da tradução, passam à complexidade ainda maior. O caso Marpurg-Couperin - assim gostaríamos de denominar a discussão levada adiante neste artigo - adéqua-se mais à discussão sobre apropriação que àquela sobre autoria. Ou seja, é possível vislumbrar em nossa discussão dois cenários, em que os elementos de uma tríade ocupam diferentes posições: i) tradução-apropriaçãoautoria e ii) apropriação-tradução-autoria. A autoria, entretanto, não possui, aqui, numa analogia à música, nem o poder da nota fundamental, e tampouco a força modulatória de uma terça. Ocorre, antes, como consequência de uma tradução, que pressupõe a apropriação, ou ainda, no segundo cenário, como consequência de uma apropriação pela via da tradução.

Pandaemonium, São Paulo, v. 24, n. 43, mai.-ago. 2021, p. 66-95 
PASCHOAL, S. - O caso Marpurg-Couperin: apropriação pela via da tradução e consequente autoria

A apropriação de que trataremos aqui não é sinônimo do apropriar-se indevidamente de coisa alheia, no sentido negativo, fato típico do ordenamento jurídico brasileiro, mesmo porque, na tendência de apropriação do século XVIII, a prática de traduzir trechos de outro autor não configuraria violação de direitos, mas, antes, reverência. Trata-se, sim, de um processo natural, semelhante ao ocorrido não apenas, mas também no surgimento de literaturas nacionais e na estabilização de literatura e língua literária alemã, e que se estende a outras áreas, como à Música e, no caso MarpurgCouperin, à área da música teórica, aí expressa na forma de um tratado.

Como dissemos na Introdução, era comum, nos séculos XVIII e XIX, que as ideias de um autor se repetissem em textos de outros autores num contexto de construção de conhecimento sobre determinada matéria, como se esse conhecimento fosse se expandindo, formando, à luz de um incessante tempus fugit, um continuum por meio de múltiplas relações intertextuais.

Isso, entretanto, não significa que seria lícito, em qualquer época passada, tomar o texto de um autor e publicá-lo sob o nome de outro, ou reclamar a autoria de um texto que não lhe pertencesse. É o que ocorreu, por exemplo, com Martinho Lutero, cuja tradução da bíblia, denuncia o reformador em sua Sendbrief vom Dolmetschen ${ }^{9}$ de 1530 , fora "roubada" pelos padres da Igreja.

Os dilemas da contemporaneidade acerca de tradução, apropriação e autoria parecem advir principalmente da impossibilidade de se fixar uma linha fronteiriça entre aquilo que pertence ao autor e aquilo que pertence ao tradutor, um limite entre onde começa e onde termina - e se termina - o exercício criativo pleno.

Cristina Carneiro Rodrigues (2005: 144) discorre, sobre apropriação, que:

Para Kanavillil Rajagopalan (2000), não há como evitar que o tradutor, de uma forma ou de outra, "se encarregue de apropriar-se da obra estrangeira" (p.127). Essa apropriação pode, entretanto, assumir diferentes formas, desde a explícita, praticada pela tradição francesa das belles infidèles, até a sutil, que acaba por apenas ressaltar o caráter "exótico" da obra estrangeira. Mesmo a prática da Alemanha clássica, que é prestigiada por Berman (1984/2002) por não ser etnocêntrica, envolve apropriação, na medida em que se dava voz ao Outro, ao estrangeiro, para afirmar a própria cultura.

Apoiados na concepção da inevitabilidade da apropriação, consideramos a possibilidade de que ela, em alguns casos concretos - como o de que tratamos aqui ocorra por meio da tradução e possa ter como última consequência a autoria. Tanto

\footnotetext{
${ }^{9}$ Há uma tradução do Prof. Mauri Furlan da Sendbrief vom Dolmetschen de Martinho Lutero, sob o título Carta aberta sobre a tradução (FURLAN 2006).

Pandaemonium, São Paulo, v. 24, n. 43, mai.-ago. 2021, p. 66-95
} 
PASCHOAL, S. - O caso Marpurg-Couperin: apropriação pela via da tradução e consequente autoria

apropriação quanto autoria envolvem posse, domínio, disputa, hierarquia. Em termos simples - e bastante polêmicos - poderíamos dizer que o autor do original é o autor do original e que o tradutor é o autor da tradução. E brevemente nos depararíamos com questionamentos acerca da criação ou concepção (em termos retóricos, inventio). Nestes mesmos termos, caberia ao tradutor, em princípio, lidar com a elocutio (verba) e, no máximo - uma vez consideradas as liberdades para uma reorganização lógica ou sequencial de ideias - da dispositio (res), embora seja difícil ou mesmo impossível separá-la da inventio.

Negar ao tradutor a inventio é tirar de seu quinhão - e de sua liberdade de escrita - toda e qualquer atividade criativa, ou seja, significa restringir sua atividade criativa apenas ao campo da elocutio, como se ele não fosse capaz de criar, mas sim de, no máximo, imitar, ainda que se trate de uma imitação criativa.

Foi justamente tal imitação criativa - conceito que se funde à aemulatio $^{10}$ no período que pretendeu transplantar do solo grego para o romano toda a filosofia - que permitiu a tradução desvinculada da atividade mecânica de se traduzir palavra por palavra, como confirma a máxima nec converti ut interpres, sed ut orator $^{11}$, de M. T. Cícero em sua obra De Optimo Genere Oratorum.

Paralelamente a domínio, posse, hierarquia, temos ainda a disputa, termo que se deriva do princípio de concorrência, de superação, presente na aemulatio, que abrange, em seu cerne, não apenas formas do dizer, mas também conteúdo. Este expediente pressupõe, mais uma vez, outro elemento, ao lado daquele de superação de modelos: o da apropriação, ocorrido principalmente à época do assim denominado surgimento de línguas e literaturas nacionais (movimento renascentista europeu). Em comparação a outros países da Europa ocidental, a Alemanha - que não constituía à época do surgimento de línguas e literaturas nacionais, uma unidade política - inicia o movimento da

\footnotetext{
${ }^{10}$ Aemulatio e imitatio não se limitavam à transposição de filosofia, mas também, num período mais longo, do teatro, da escultura e da religião. No âmbito da imitatio auctorum, a aemulatio é um princípio aplicável a textos e autores exemplares. Nossa intenção, ao mencionarmos a aemulatio, é mostrar ao leitor uma forma possível de apropriação, e não afirmar que a aemulatio tenha sido utilizada no caso concreto da incorporação de trechos traduzidos da obra de Couperin na obra de Marpurg.

${ }^{11}$ Palavras de Cícero em De Optimo Genere Oratorum, parte V: "Traduzi, então, dos áticos dois discursos notáveis e contrários entre si, um de Ésquino, outro de Demóstenes, autores dos mais eloquentes. E não os traduzi como um tradutor, mas como um orador, usando os mesmos argumentos, tanto na sua forma quanto nas suas figuras de linguagem, em termos adequados à nossa cultura" (CÍ́CERO 2011). No original: "Converti enim ex Atticis duorum eloquentissimorum nobilissimas orationes inter seque contrarias, Aeschinis et Demosthenis; nec converti ut interpres, sed ut orator, sententiis isdem et earum formis tanquam figures, verbis ad nostram consuetudinem aptis." Para um aprofundamento do mote apresentado, recomendo a leitura de Longiano (2006).
}

Pandaemonium, São Paulo, v. 24, n. 43, mai.-ago. 2021, p. 66-95 
PASCHOAL, S. - O caso Marpurg-Couperin: apropriação pela via da tradução e consequente autoria apropriação literária estrangeira, que tinha como principal característica o retorno à Antiguidade greco-romana, com certo atraso. Porém, quando o faz, recebe de seu atraso um trunfo: dispõe, diferentemente das literaturas de países vizinhos, não de uma fonte apenas, mas de duas: i) a literatura da Antiguidade greco-romana (comum aos países vizinhos) e ii) a literatura dos países vizinhos.

A apropriação de que tratamos, ao mesmo tempo em que ocorre por meio da tradução, extrapola-a, se entendida esta última stricto sensu. Numa direção oposta ao modo de traduzir dos franceses ${ }^{12}$, iluministas e românticos alemães prepararam o terreno para receber o fluxo cultural e literário que culminaria na Weltliteratur de Goethe (cf. BERMAN 1992: 54). No estágio de apropriação, os alemães tinham um modo diferente daquele dos franceses para receber, ou ainda, experimentar o estrangeiro. Muito embora tenha havido, em movimentos culturais precedentes (cf. Sprachgesellschaften ou academias linguísticas na Alemanha durante o século XVII) a intenção da Verdeutschung como alemanização, assim como ocorrido com o afrancesamento pressuposto pelas belles infidèles, a Verdeutschung romântica parecia optar por um modo de acomodação do elemento estrangeiro por meio de uma tradução mais propensa à tradução literal.

Segundo Berman (1992: 35; tradução nossa), a "teoria alemã de tradução posiciona-se claramente contrária às traduções segundo o modo francês"13, um pensamento que pode ser ilustrado com a crítica de August Wilhelm Schlegel ao modo de apropriação francês:

Outras nações têm adotado uma fraseologia totalmente convencional em poesia, de modo que é totalmente impossível fazer uma tradução poética de qualquer coisa em sua língua. O francês é um exemplo... É como se eles quisessem que todo estrangeiro dentre eles se comportasse e se vestisse de acordo com os costumes de seu país, e isto explica por que eles nunca realmente conseguem conhecer o estrangeiro (apud BERMAN 1992: 36 tradução nossa) ${ }^{14}$.

A citação acima nos mostra que, por meio da tradução, é possível apropriar-se de um saber de modos diversos. O que define o modo de apropriação é a postura do apropriador frente ao conhecimento-objeto apropriado: é o exercício de ponderação do tradutor, que lhe permitirá - em primeiro lugar, de acordo com sua intenção - definir as

\footnotetext{
${ }^{12}$ Poppi (2013).

13 "German theory of translation consciously positions itself against those translations 'after the French manner"”.

14 "Other nations have adopted a totally conventional phraseology in poetry, so that it is totally impossible to make a poetic translation of anything whatsoever into their language. French is an example... It is as if they wanted every foreigner among them to behave and to dress according to the customs of the land, and that explains why they never get to know the foreign".
}

Pandaemonium, São Paulo, v. 24, n. 43, mai.-ago. 2021, p. 66-95 
PASCHOAL, S. - O caso Marpurg-Couperin: apropriação pela via da tradução e consequente autoria

bases para a recepção do conhecimento, que se tornará conhecimento-objeto e, a partir desta recepção, como este conhecimento será tratado. Observemos: para muito além de questões linguísticas - que não se dispensam das discussões sobre tradução, pois que seu elemento palpável por excelência - as múltiplas possibilidades do tradutor conferem determinada plasticidade ao conhecimento vindo por meio do texto. A partir do momento em que existe a possibilidade de moldar o conhecimento recebido - então um elemento plástico - existe apropriação.

Ainda no tocante aos modos de apropriação, é deveras interessante notar a postura de Johann Gottfried von Herder (1744-1803). Berman (1992: 38; tradução nossa) destaca que "os problemas de tradução, à medida que afetam a relação da língua materna e línguas estrangeiras, têm frequentemente uma intensidade imediata para Herder, que se expressa em termos quase amorosos e eróticos"15. Herder afirma:

Não é para desaprender minha língua que aprendo outras línguas; não é para mudar os hábitos de minha educação que viajo entre povos estrangeiros: não é para perder a naturalidade de minha terra natal que me torno um estrangeiro naturalizado: se fosse para agir assim, eu mais perderia que ganharia. Caminho, entretanto, entre jardins estrangeiros para colher flores para o meu idioma, como noivo de minha maneira de pensar: eu observo os modos estrangeiros para sacrificar os meus ao gênio de minha terra natal, como frutos amadurecidos sob um sol estrangeiro (apud BERMAN 1992: 38; tradução nossa) ${ }^{16}$.

A atitude de Herder em direção à apropriação expõe a possibilidade de expansão de sua própria cultura por meio do "abrigo" oferecido ao estrangeiro. Ou seja, busca conhecer novas plagas para delas trazer a seu solo aquilo que ainda não há ali. Sua inclinação ao estrangeiro é intencional e possui motivação: trazer os frutos (conhecimentos) de outros para que sejam cultivados e amadureçam sob outro sol, isto é, sejam cultivados em outro solo, somando-os à sua cultura e, consequentemente, expandido-a. Esta passagem de Herder nos remete ao ideal da apropriação, em que ele de um modo muito semelhante, num período anterior (século XVII) - mostrava-se implícito nas formas de contato com o elemento estrangeiro, no nível linguístico-retórico. Como o intuito da ilustração disso, apresentamos a seguir uma breve passagem da obra Poetischer Trichter (1647-1653) de Georg Philipp Harsdörffer (1607-1658), em que é

\footnotetext{
15 "The problems of translation, as far as they affect the relation of the mother-tongue to foreign languages, often have an immediate intensity for Herder, which is expressed in almost amorous and sexual terms." 16 "It is not to unlearn my language that I learn other languages; it is not to exchange the habits of my education that I travel among foreign people: it is not to lose the citizenship of my fatherland that I become a naturalized foreigner: if I were to act in this way, I would lose more than I would gain. But I walk through foreign gardens to pick flowers for my language, as the betrothed of my manner of thinking: I observe foreign gardens in order to sacrifice mine to the genious of my fatherland, like fruits ripened under a foreign sun."
}

Pandaemonium, São Paulo, v. 24, n. 43, mai.-ago. 2021, p. 66-95 
PASCHOAL, S. - O caso Marpurg-Couperin: apropriação pela via da tradução e consequente autoria

coincidente, inclusive, a figura do noivo, no autor de século XVII representada pelo "jovem enamorado":

Da mesma forma como um jovem enamorado, que viaja ao exterior, encoraja-se a trazer consigo várias singularidades graciosas ao amor deixado para trás, deve um amante de nossa excepcionalmente bela língua materna esforçar-se para trazer à sua mui amada terra natal tudo o que encontrar em livros escritos em outras línguas, e que talvez lhe sejam desconhecidos. Deve ainda esforçar-se para imitar elegantemente não apenas o conteúdo, mas também a condição para o aprendizado do desconhecido e das formas de ornamentação desta língua. Tudo isto deve ocorrer com discernimento e, em qualquer hipótese, de forma útil e oportuna (HARSDÖRFFER 1939: 47-48; tradução nossa) ${ }^{17}$.

O conceito de apropriação atrelado à imitação é mais latente em Harsdörffer que em Herder, pois em Harsdörffer, pelo contexto cultural (cf. al. Sprachpflege, ingl. language policy) a imitação (retórica) é um expediente pressuposto. De qualquer modo, a visita ao "estrangeiro" permite experimentá-lo, para, de modo literal ou expandido, espelhado ou direto, apropriar-se dele. É o que vemos no caso Marpurg-Couperin. A reverência ao autor é clara nos prefácios das edições de 1750 e 1751. Não podemos dizer, ao certo, que a reverência permanece nas edições posteriores, em que ou o prefácio é excluído ou é excluída do prefácio a menção ao mestre francês.

É certo que, para o círculo relativamente restrito de músicos e acadêmicos de meados do século XVIII, o discurso propedêutico de Marpurg à primeira parte de sua obra Die Kunst das Clavier zu spielen era reconhecido como continente dos ensinamentos de Couperin. Com ou sem menção a seu nome, é um caso de apropriação. Ocorre que o apagamento de seu nome dos prefácios, em edições posteriores - seja motivado por questões editoriais, seja uma opção pessoal de Marpurg - leva ao fato de que tais conhecimentos, ao longo do tempo, estejam sob o risco de não serem mais reconhecidos, em primeira instância, como de Couperin. Com isso, temos uma questão sobre apropriação tendente à autoria.

Esta fusão de parte de um conhecimento em determinada obra - em que se destaca o caráter apropriatório - leva-nos também à ideia de construção de um continuum, de um conhecimento partilhado, que parece não ter começo nem fim. Na formação deste continuum, sobrevindo por relações de múltiplas intertextualidades, a busca incessante

\footnotetext{
${ }^{17}$ „Gleichwie ein junger Freier, der im fremde Länder reiset, bemühet ist, seiner hinterlaßnen Liebsten mancherlei zierliche Seltsamkeiten einzukramen und mitzubringen, also soll ein Liebhaber unsrer übertrefflich schönen Muttersprache sich befleißigen, alles, was er in fremden Sprachen Büchern begegnet, dem vielgeliebten Vaterlande, welches vielleicht solches nicht gesehen, zu überbringen, und zwar nicht nur dem Inhalt, sondern der Verfassung zierlich nachahmen, zu Belernung der Unwissenden und Ausschmuckung hochgesagter Sprache. Solches muß mit Verstand und soviel dienlich und tunlich beschehen.“
}

Pandaemonium, São Paulo, v. 24, n. 43, mai.-ago. 2021, p. 66-95 
PASCHOAL, S. - O caso Marpurg-Couperin: apropriação pela via da tradução e consequente autoria

pela origem primeira, muitas vezes, fracassa, sendo de pouca contribuição. Nesse sentido, acerca do que diz Roland Barthes (1915-1980) sobre a morte do autor, Comellas (2009: 17) pondera:

Barthes denuncia nele (artigo sobre a morte do autor) a falsidade da origem: não é possível estabelecer a origem de um texto em um autor, uma vez que este "deveria saber que a 'coisa' interior que tem intenção de 'traduzir' não é em si mesma nada mais do que um dicionário já composto, no qual as palavras não se podem explicar senão através de outras palavras, e assim indefinidamente (BARTHES 1968: 69)".

Comellas (2009: 17) conclui que "todo texto faz parte de uma série" e que, além disso, buscar a intertextualidade não é algo que se deva confundir com a procura da origem. Nesse sentido é que devemos buscar entender as relações entre tradução e apropriação no caso Marpurg-Couperin.

O conhecimento, à medida que se expande [o que pressupõe a presença do Outro], passa, independentemente de como é divulgado, a pertencer a diversos autores e atores. Respeita-se, naturalmente, o gênio criativo que primeiro o lança à luz, e nisto não nos parece haver qualquer mal. Entretanto, difuso, converte-se em algo dos outros e para os outros, no próprio ato de sua recepção, pois o ato do conhecer é, por si, um ato de apropriação, ou seja: quidquid recipitur, ad modum recipientis recipitur, isto é, qualquer coisa recebida é recebida ao modo do recipiente ${ }^{18}$, e não segundo a forma daquele que o emana, pois o elemento emanado (conhecimento), ao ser recebido, passa a ser conhecimento-objeto (numa quase relação de passividade) e afeta (ativamente) de modo diverso os que o apreendem/recebem: trata-se de um processo de ressignificação.

Assim, são autores do texto não apenas aqueles que o escrevem e o traduzem, mas também aqueles que o leem e que, desse modo, permitem a existência contínua de seu sentido num coletivo intelectual. A despeito disso, vemo-nos ainda presos a discussões que envolvem a autoria: consequência de uma concepção de tradução, formada ao longo dos séculos, que privilegia o lugar do original e a figura do autor, o que precisamente reforça o discurso de um assunto de que se têm preservado nas últimas décadas os Estudos da Tradução: a fidelidade (ao autor, ao original).

Coracini (2005: 40) expõe:

\footnotetext{
${ }^{18} \mathrm{O}$ trecho que dá origem a esta frase é "Omne enim quod cognoscitur non secundum sui vim sed secundum cognoscentium potius comprehenditur facultatem", presente na obra Philosophiae Consolationis, Livro V, IV, 75, de Boécio (480-524 ou 525). O princípio encontra-se também em diversas passagens da Summa Theologiae de Tomás de Aquino (q.14, a.1,ad.3; q.16, a.1; q.19, a.6, ad.2): "Cogitum [...] est in cognoscente secundum modum cognoscentis". Trata-se de um axioma da filosofia escolástica que afirma a imutabilidade da natureza daqueles que percebem sensações e realidade.
}

Pandaemonium, São Paulo, v. 24, n. 43, mai.-ago. 2021, p. 66-95 
PASCHOAL, S. - O caso Marpurg-Couperin: apropriação pela via da tradução e consequente autoria

O primeiro eixo se encontra centrado no autor ou no texto [...] Aquele (eixo) cujo foco recai sobre o autor do texto exige do tradutor um alto grau de fidelidade às intenções do autor, às ideias que ele defende, cujas marcas se encontram impressas nas palavras, nos argumentos usados. Como consequência, é possível afirmar que o foco está no texto, cujo sentido único, impresso nos signos linguísticos que o constituem, deve ser garantido e respeitado na tradução [...].

Se, por um lado, a observância exagerada a este primeiro eixo, de certo modo acaba por restringir a criatividade do tradutor - não que uma tradução fiel, a depender, primeiramente, do que se entende por fidelidade, não exija criatividade, principalmente em períodos da história em que a ausência de fidelidade podia levar o tradutor à fogueira, como ocorreu com Étienne Dolet (1509-1546) - por outro, foi também sua concretização mais modesta - a tradução literal - que predominou em períodos de ampla recepção do estrangeiro. Além disso, essa mesma concretização permitiu, num primeiro momento, constatar que as coincidências entre partes das obras de Marpurg e Couperin não se tratavam apenas de loci communes do ensino de instrumentos de teclado, mas, de fato, de traduções.

A constante divulgação desses conhecimentos por F. W. Marpurg torna-o, em certo momento, o seu autor. Para isso, basta imaginarmos leitores não especializados, sem qualquer contato (prévio) com a obra de Couperin: esses leitores atribuirão os preceitos de Couperin apresentados na obra de Marpurg a Marpurg, e não a Couperin. À medida que exclui o nome do autor francês de seus prefácios posteriores, e que acomoda as ideias - por meio também da tradução - em uma nova disposição, torna-se também autor destes conhecimentos: um autor por apropriação ocorrida pela via da tradução.

\section{Considerações finais}

Discutimos neste artigo aspectos da apropriação no interior de uma tríade possível em duas posições distintas: i) apropriação-tradução-autoria, ii) tradução-apropriação-autoria. Pelo teor do que apresentamos, acreditamos ineficaz apresentarmos inversões em que a autoria configurasse como primeiro ou segundo elemento, já que, nos dois modelos (posições) propostos, ela ocorre como consequência última.

Oito trechos na Preparação à primeira parte da obra Die Kunst das Clavier zu spielen, de Friedrich Wilhelm Marpurg, espelham partes da obra L'Art de toucher le clavecin, de François Couperin, um espelhamento ocorrido pela via da tradução, o que 
PASCHOAL, S. - O caso Marpurg-Couperin: apropriação pela via da tradução e consequente autoria

não constitui nenhum problema para as discussões sobre apropriação, e nem afasta qualquer possibilidade de reflexão sobre a matéria.

Há, contudo, uma especificidade no processo de apropriação (não só, mas também pela via da tradução): no prefácio das edições de 1750 e de 1751, o autor alemão faz questão de esclarecer a seus leitores que se fundamentou no autor francês e, nos prefácios das edições seguintes (temos como base a quarta edição, de 1762), tal esclarecimento desaparece: justamente sua ausência nos motivou a uma discussão sobre apropriação pela via da tradução que culminasse, de certo modo, na autoria.

O expediente da apropriação faz-se tão evidente, nesta obra de Marpurg, que Moroney (2003) põe em xeque, no título de seu capítulo (Couperin, Marpurg e Roeser: uma art de toucher le clavecin germânica ou uma wahre Art francesa?) ${ }^{19}$ se a matéria é l'art de toucher le clavecin (arte de tocar instrumentos de teclado, em francês) germânica ou se a wahre Art (maneira correta/verdadeira) francesa. Isto é: o expediente da apropriação é tão claro, que parece ser permitido falar de um conhecimento objeto francês germanizado ou de um conhecimento produzido alemão afrancesado, o primeiro referindo-se à fonte e, o segundo, à recepção, elementos comuns à tradução.

A ausência do esclarecimento aos leitores, no prefácio à edição de 1762, leva a algumas hipóteses, expressas em nossas discussões anteriores (Die Kunst das Clavier zu spielen: Os Prefácios). Mesmo assim, na busca por algo que pudesse tê-la motivado, encontramos em Moroney (2003: 124; tradução nossa) um trecho que reforça o caráter apropriatório em Marpurg, sem necessariamente haver, por parte do autor alemão, alguma preocupação com a reverência ou indicação do conhecimento apropriado:

Considerando-se a escolha do sistema de afinação de Marpurg, não é de surpreender que, posteriormente, ele explique que há "vinte e quatros tonalidades ou modos, doze maiores e doze menores", embora ele não se refira de modo específico ao Cravo Bem Temperado. Nem o nome de Couperin, nem o nome de Bach aparecem alguma vez, embora as sombras destes dois homens pairem sobre o livro, de modos diversos ${ }^{20}$.

A relação entre Marpurg e a obra de Couperin - já tornada evidente pelo prefácio das edições de 1750/51, é reforçada por Moroney (2003: 123; tradução nossa) em:

\footnotetext{
19 "Couperin, Marpurg and Roeser: a Germanic Art de Toucher le Clavecin or a French Wahre Art?"

20 "Given Marpurg's choice of tuning system, it comes as no surprise that he later explains that there are 'twenty-four keys or modes, twelve major and twelve minor', although he does not refer specifically to the Well-Tempered Clavier. The names of neither Couperin nor Bach ever appear, yet the shadows of both men hover over the book, in different ways".
}

Pandaemonium, São Paulo, v. 24, n. 43, mai.-ago. 2021, p. 66-95 
PASCHOAL, S. - O caso Marpurg-Couperin: apropriação pela via da tradução e consequente autoria

[...] Todavia, era perceptível uma nítida tendência francesa nos Principes du clavecin. O fato de o título original, Die Kunst das Clavier zu spielen, ser uma tradução exata em alemão de L'Art de Toucher le Clavecin, tomada juntamente com sua formação francesa, sugere que ele tinha consciência do texto do Couperin ${ }^{21}$.

Para encerrarmos nossa discussão, é necessário apontar que: i) a apropriação do conhecimento por Marpurg contribui para a formação de um continuum de ideias sobre determinada matéria ao longo do tempo que, por meio da repetidas ocorrências, dispõe de certa potencialidade para que se tornem tendências; ii) a apropriação de ideias de Couperin por Marpurg ocorrem não só, mas também pela via da tradução, e este último cenário é o que se levou em conta nas pesquisas para a elaboração deste artigo; iii) a apropriação é um processo que pressupõe fortemente a alteridade; iv) a apropriação - seja pela via da tradução ou não - nem sempre tem como consequência a autoria.

No caso das discussões apresentadas neste artigo, a apropriação, somada à ausência de um esclarecimento sobre determinada fonte - esclarecimento feito a prioriem prefácios de edições posteriores às de 1750/51 implica a consequente autoria, motivada, talvez, pelo desejo de conferir à Alemanha a primazia como centro de crítica e de teoria da música erudita, ou, ainda, pelo caráter polêmico e irascível de Marpurg, que o tenha levado, impetuosamente, a atropelar reputações e apropriar-se - aqui no sentido mais literal possível - das ideias de outros autores.

\section{Referências bibliográficas}

BACH, Carl Philipp Emanuel. Ensaio sobre a maneira correta de tocar teclado. Tradução de Fernando Cazarini. Campinas: Editora da Unicamp, 2009.

BACH, Carl Philipp Emanuel. Versuch über die wahre Art, das Clavier zu spielen. Leipzig: Breitkopf \& Härtel, 1957 [1753/1762].

BAKER, Mona. In other words: a coursebook on translation. London: Routledge, 1992.

BERMAN, A. The experience of the foreign: culture and translation in romantic Germany. Nova York: Suny, 1992.

CíCERO, Marco Túlio. De optimo genere oratorum $=\mathrm{O}$ melhor gênero de oradores. Tradução de Brunno Vinicius Gonçalves Vieira e Pedro Colombaroli Zoppi. Scientia Traductionis, v. 10, 4-15, 2011. https://periodicos.ufsc.br/index.php/scientia/article/view/19804237.2011n10p4/19983 (04/07/2020).

COMELLAS, Pere. Autoria contra tradução ou tradução como autoria: Milan Kundera, Jorge Luis Borges e o fim do indivíduo. Cadernos de Tradução, v. 2, n. 24, 9-30, 2009.

\footnotetext{
21 " [...] Nevertheless, a distinct French bias is detectable in the Principes du clavecin. The fact the the original title, Die Kunst das Clavier zu spielen, is an exact translation into German of L'Art de Toucher le Clavecin, taken in conjunction with his French training, suggests that he was aware of Couperin's text".
}

Pandaemonium, São Paulo, v. 24, n. 43, mai.-ago. 2021, p. 66-95 
PASCHOAL, S. - O caso Marpurg-Couperin: apropriação pela via da tradução e consequente autoria

https://periodicos.ufsc.br/index.php/traducao/article/download/2175-

7968.2009v2n24p9/12215. (10/05/2020).

CORACINI, Maria José R. Faria. Discurso sobre tradução: aspectos da configuração identitária do tradutor. Tradterm, v. 11, 29-51, 2005. https://doi.org/10.11606/issn.2317-9511. tradterm.2005.49674. (04/07/2020).

COUPERIN, François. l'art de toucher le clavecin. Wiesbaden: Breitkopf \& Härtel, 1933 [1716].

HARSDÖRFFER, Georg P. Poetischer Trichter (1647-1653). Herausgegeben von Reginald Marquiero. Berlin: Die Rabenpresse, 1939.

HOLMES, James S. The name and nature of translation studies. In: VENUTI, Lawrence (ed.). The Translation Studies Reader. London; New York: Routledge, 2004, 180-192.

Longiano, Sebastiano Fausto da. Diálogo sobre o modo de traduzir de uma língua a outra. Tradução de Mauri Furlan. In: FuRLAN, Mauri (org.) Clássicos da teoria da tradução: Renascimento. Florianópolis: UFSC/NUPLITT, 2006, 317-373.

LUTERO, Martinho. Carta aberta sobre a tradução. In: FuRLAN, Mauri (org.) Clássicos da teoria da tradução: Renascimento. Florianópolis: UFSC/NUPLITT, 2006, 91-115.

MARPURG, Friedrich Wilhelm. Anleitung zum Clavierspielen. Hildesheim: Georg Olms Verlag, 1970 [1755].

MARPURG, Friedrich Wilhelm. Der critische Musicus an der Spree. Hildesheim: Georg Olms Verlag, 1970 [1750]. Erster Band.

MARPURG, Friedrich Wilhelm. Die Kunst das Clavier zu spielen. Berlin: Henning, 1750. https://reader.digitale-sammlungen.de/de/fs1/object/display/bsb10527415_00013.html. (09/07/2020).

MARPURG, Friedrich Wilhelm. Die Kunst das Clavier zu spielen. Berlin: Haude und Spener, 1751. https://reader.digitale-sammlungen.de//resolve/display/bsb10598996.html. (09/07/2020).

MARPURG, Friedrich Wilhelm. Die Kunst das Clavier zu spielen. Berlin: Haude und Spener, 1762. https://reader.digitale-sammlungen.de/de/fs1/object/display/bsb10598997_00005.html. (09/07/2020).

MARPURG, Friedrich Wilhelm. Principes du clavecin. Hildesheim: Georg Olms Verlag, 1970 [1756].

Moroney, Davitt. Couperin, Marpurg and Roesner: a Germanic 'Art de Toucher le Clavecin' or a French 'Wahre Art”? In: HOGWOOD, Christopher (org.). The keyboard in Baroque Europe. Cambridge: Cambridge University Press, 2003, 111-130.

PoPPI, C. Século XVII na França: Les Belles Infidèles, Racine e o modelo dos clássicos antigos. In: Non Plus, v. 2, n. 3, 29-43, 2013. https://doi.org/10.11606/issn.2316-3976.v2i3p29$43(04 / 07 / 2020)$.

QUANTZ, Johann Joachim. Essai d'une méthode pour apprendre à jouer de la flute traversiere avec plusieurs remarques pour server au bon gout de la musique le tout eclairci par des exemples et par XXIV tailles douces. Berlin: Chretien Frederic Voss, 1752. https://archive.org/details/imslp-einer-anweisung-die-flte-traversiere-zu-spielen-quantzjohann-joachim/page/n6/mode/2up. (10/05/2020).

QUANTZ, Johann Joachim. Versuch einer Anweisung, die Flöte traversière zu spielen. Mit einem Vorwort, Bemerkungen, Ergänzungen und Registern von Horst Augsbach. Kassel; Basel; London: Bärenreiter, 1983 [1752]. https://archive.org/details/VersuchEiner AnweisungDieFlteTraversiereZuSpielen17521906/mode/2up. (10/05/2020).

RODRIGUES, Cristina Carneiro. Tradução e viagem: relações de poder. Revista Gragoatá, v. 18, n. 1, 141-149, 2005. https://periodicos.uff.br/gragoata/article/viewFile/33281/19268. (04/07/2020).

SAger, Juan C. Text types and translation. In: Trosborg, Anna (org.). Text typology and translation. Amsterdam; Philadelphia: John Benjamins, 1997, 25-41.

Pandaemonium, São Paulo, v. 24, n. 43, mai.-ago. 2021, p. 66-95 
PASCHOAL, S. - O caso Marpurg-Couperin: apropriação pela via da tradução e consequente autoria

Tomás, de Aquino, Santo. Summa Theologiae. Corpus Thomisticum Textum Leoninum Romae 1888 editum et autoamato translatum a Roberto Busa SJ in taenias magneticas denuo recognovit Enrique Alarcón atque instruxit. Pampilonae: Ad Universitatis Studiorum Navarrensis, 2001. http://www.corpusthomisticum.org/sth0000.html. (11/05/2020).

WiLliams, Jenny; CHESTERMAN, Andrew. The map: a beginner's guide to doing research in Translation Studies. Manchester: St. Jerome, 2002.

Recebido em 22 de maio de 2020 Aceito em 3 de agosto de 2020 